\title{
Aerobic Oxidation of Veratryl Alcohol to Veratraldehyde with Heterogeneous Ruthenium Catalysts
}

\author{
Melián Rodriguez, Mayra; Shunmugavel, Saravanamurugan; Kegnæs, Søren; Riisager, Anders
}

Published in:

Topics in Catalysis

Link to article, DOI:

10.1007/s11244-015-0472-z

Publication date:

2015

Document Version

Peer reviewed version

Link back to DTU Orbit

Citation (APA):

Melián Rodriguez, M., Shunmugavel, S., Kegnæs, S., \& Riisager, A. (2015). Aerobic Oxidation of Veratryl Alcohol to Veratraldehyde with Heterogeneous Ruthenium Catalysts. Topics in Catalysis, 58(14), 1036-1042. https://doi.org/10.1007/s11244-015-0472-z

\section{General rights}

Copyright and moral rights for the publications made accessible in the public portal are retained by the authors and/or other copyright owners and it is a condition of accessing publications that users recognise and abide by the legal requirements associated with these rights.

- Users may download and print one copy of any publication from the public portal for the purpose of private study or research.

- You may not further distribute the material or use it for any profit-making activity or commercial gain

- You may freely distribute the URL identifying the publication in the public portal 


\title{
Aerobic oxidation of veratryl alcohol to veratraldehyde with heterogeneous ruthenium
}

\section{catalysts}

\author{
M. Melián-Rodríguez, S. Saravanamurugan, S. Kegnæs and A. Riisager* \\ Centre for Catalysis and Sustainable Chemistry, Department of Chemistry, Building 207, Technical \\ University of Denmark, DK-2800 Kgs. Lyngby, Denmark
}

*Corresponding author: Tel.: (+45) 45252233, Fax: (+45) 45252371, E-mail: ar@kemi.dtu.dk

\begin{abstract}
Lignin is a complex polymeric molecule constituting various linkages between aromatic moieties. Typically, the $\beta-O-4$ linkage accounts for more than half of the linkage structures present in lignin. The present study focuses on the oxidative transformation of veratryl alcohol (VA) - a compound that can be formed by cleavage of $\beta-\mathrm{O}-4$ linkages in lignin - to veratraldehyde (VAld) with air using ruthenium supported on $\gamma$-alumina or silica as catalyst with water or methanol as solvent in a batch reactor. $\mathrm{Ru} / \mathrm{Al}_{2} \mathrm{O}_{3}$, prepared with ruthenium (IV) oxide hydrate showed superior catalytic activity, yielding $89 \%$ VAld in water at $160{ }^{\circ} \mathrm{C}$ with 5 bar air pressure after $8 \mathrm{~h}$ of reaction. Prolonged reaction time led to significant formation of the decarbonylated product veratrol from VAld. When the reaction was completed under 20 bars of argon in methanol instead of water, the methyl ether of VA (i.e. 1,2-dimethoxy-4-(methoxymethyl)benzene) prevailed, indicating that methanol protecting the hydroxyl group in VA from being oxidized to VAld. Catalysts containing alternative transition metals ( $\mathrm{Mn}, \mathrm{Co}, \mathrm{Cu}$ and $\mathrm{Ag}$ ) supported on $\mathrm{Al}_{2} \mathrm{O}_{3}$ gave significantly lower activities compared to $\mathrm{Ru} / \mathrm{Al}_{2} \mathrm{O}_{3}$ under identical reaction conditions. The $\mathrm{Ru} / \mathrm{Al}_{2} \mathrm{O}_{3}$ catalyst was
\end{abstract}


reused in three consecutive reaction runs in water, but a significantly lower VAld yield was obtained after the third cycle possibly due to leaching of Ru from the support.

Keywords: Heterogeneous catalysis, Ruthenium, Oxidation, Veratryl alcohol, Veratraldehyde.

\section{Introduction}

Catalytic transformations of lignocellulosic biomass-derived chemicals into value-added chemicals/fuels have become increasingly important in the past decade, due to their potential application as sustainable supplement or replacement of fossil-based chemicals/fuels [1]. Most focus has been devoted to valorization of carbohydrate-based compounds originating from the cellulose and hemicellulose in biomass. Hence, numerous reports describe the conversion of glucose (model compound for cellulose) and xylose (model compound for hemicellulose) into selective products [2-5]. However, it is now recognized that suitable catalytic systems also needs to be developed for conversion of the lignin fraction in order to create sustainable bio-refineries, since lignin typically constitutes $30 \%$ of the carbon content and $40 \%$ of the energy content of lignocellulosic biomass [6].

In lignocellulosic material the composition as well as the molecular weight and structure of the lignin differ from plant to plant (hard and soft wood, grass etc.), impeding the developments on lignin valorization processes [7-8]. However, three monolignol monomers p-coumaryl, coniferyl and sinapyl alcohol are common building blocks. These monomers are connected with various linkages with the most common one being the $\beta-O-4$ linkage (Fig. 1) [7]. Due to the structural complexity it is difficult to choose a unique model compound - as there is none - that can reflect/represent lignin conversion, and thus exemplify the bottleneck of the process for the 
selective conversion of lignin towards targeted products. Consequently, a particular model compound is often selected to represent a specific linkage present in the lignin, and only few works have studied the reactivity of pseudo mixtures of lignin-derived model compounds [9].

One of the viable methods for the valorisation of lignin and lignin model compounds is oxidative depolymerisation with environmentally friendly oxidants such as oxygen (air) or $\mathrm{H}_{2} \mathrm{O}_{2}$. Since lignin contains many hydroxyl groups, it is susceptible to oxidation and oxidative depolymerisation. The oxidative depolymerisation/cracking cleaves aryl ether bonds, for example $\beta-\mathrm{O}-4$ and $4-\mathrm{O}-5$, and other linkages within the lignin (Fig. 1). The major oxidation products from such cleavage would be aromatic aldehydes or carboxylic acids, depending on the severity of the reaction conditions [10]. In this connection, oxidation of methyl hydroxy (including benzylic) groups to the corresponding aldehyde or acid is of importance as such moieties are abundant in lignin [11-14].
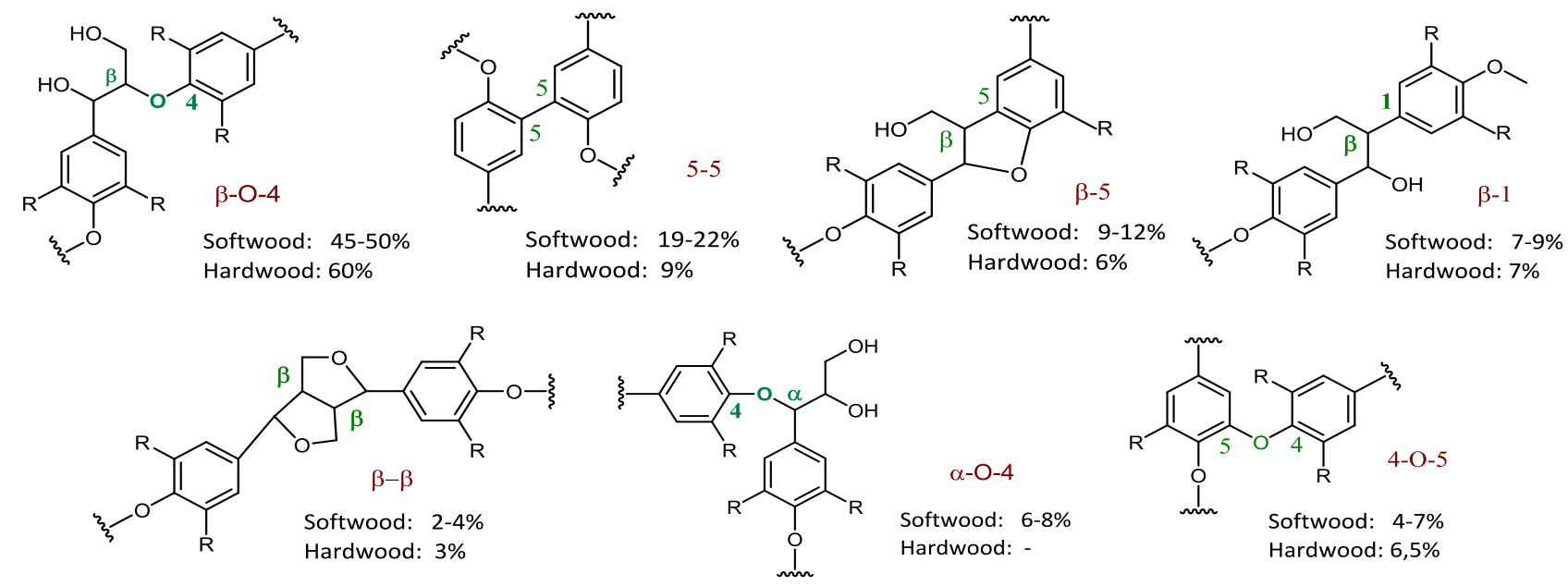

Fig. 1 Representative linkages and abundance of lignin present in soft and hardwood [7].

A reaction system representing the oxidative cleavage of $\beta-\mathrm{O}-4$ linkages in lignin is the oxidation of veratryl alcohol (3,4-dimethoxybenzyl alcohol, VA) to the corresponding veratraldehyde $(3,4$ dimethoxybenzaldehyde, VAld) (Scheme 1). VAld is a useful flavorant and odorant and its formation has been comprehensively studied by both enzymatic and homogeneous catalyst systems. 
Kirk and Farrell have reviewed early work up to 1987 on enzymatic degradation of lignin and lignin model compounds, including the catalytic oxidation of VA to VAld by ligninase [16]. DíazGonzaléz et al. have later extensively studied the enzymatic oxidation of VA with laccase in the presence of several phenolic compounds as mediator/enhancer, but in all cases the yields to VAld remained low $(\leq 20 \%)$ [11]. Larson et al. have recently improved the laccase mediated oxidation and reported $94 \%$ of isolated VAld yield under optimized reaction condition [17]. Despite the advanced made on establishing enzymatic transformations of lignin and lignin model compounds these reaction systems suffer from well-known drawbacks such as, e.g. poor thermal stability, narrow $\mathrm{pH}$ operating range and enzyme deactivation over time making periodic replacement of enzyme necessary to maintain a good activity, which limit their general use.

Various types of homogeneous catalyst systems comprising phorphyrins, Schiff-bases, polyoxometalates and other metal salts have been applied as alternatives to enzymes for the transformation of VA to VAld in the presence of stoichiometric oxidants $\left(\mathrm{H}_{2} \mathrm{O}_{2}, \mathrm{t}-\mathrm{BuOOH}, \mathrm{NaClO}\right.$, $\mathrm{PhIO} \mathrm{KHSO}_{5}$, etc.) [18-23]. Thus, M-phorphyrin based catalysts with $\mathrm{M}=\mathrm{Mn}, \mathrm{Fe}$ or Co all gave good yields (up to 90\%) of VAld in the presence of $\mathrm{H}_{2} \mathrm{O}_{2}$ at room temperature [23]. In contrast, comparative lower yields of $\leq 7$ and $43 \%$ were obtained with Co-sulphosalen [24-25] and Co-salen complexes [26], respectively. Quantitative conversion was, however, obtained with $\mathrm{Cu}-9,10$ diamine-phenanthrene [27] as well as when using hexacyanoruthenate(II) in combination with either laccase or an electrolysis cell [28]. Several other catalyst systems based on Co, Cu or Ru salts have also been reported to provide VAld yields in the range 73-84\% [29-30]. Despite excellent catalytic performance of many of the reported homogeneous catalyst systems they are inherently difficult to recover and recycle, which limit their general usability. 
In contrast to homogeneous catalysts, solid catalysts with supported metals/metal oxides can easily be recovered from liquid reaction mixtures. Moreover, such catalysts can often be recycled provided that the metal leaching is negligible and applied at elevated reaction temperatures. For the aerobic oxidation of $\mathrm{VA}$ a combined $\mathrm{Ru}$-imidazolite/CuO ionic liquid catalyst system has been reported to yield up to $95 \%$ of VAld at $130{ }^{\circ} \mathrm{C}$ [31]. However, the recyclability of the catalyst system was not documented. Recently, Yamaguchi and Mizuno have reported $\mathrm{RuO}_{\mathrm{X}}$ supported on $\gamma$-alumina to be an effective and reusable heterogeneous catalyst for aerobic oxidation of both activated and non-activated alcohols in presence of sulfur, nitrogen and carbon-carbon double bonds [32]. Moreover, Ru-based catalysts have been demonstrated to play an important role in hydrogenation and hydrogenolysis reactions [31-36]. Combined, this makes Ru-based catalysts interesting to examine in the context of lignin valorization.

In the present work we have prepared, characterized and examined the performance of $\mathrm{RuO}_{\mathrm{X}}$ supported on silica $\left(\mathrm{Ru} / \mathrm{SiO}_{2}\right)$ and alumina $\left(\mathrm{Ru} / \mathrm{Al}_{2} \mathrm{O}_{3}\right)$ as catalysts for the oxidation of VA to VAld with air in both water and methanol. Analogous $\mathrm{M} / \mathrm{Al}_{2} \mathrm{O}_{3}$ catalysts $\left(\mathrm{M}=\mathrm{MnO}_{\mathrm{X}}, \mathrm{CoO}_{\mathrm{X}}, \mathrm{CuO}_{\mathrm{X}}\right.$ and $\left.\mathrm{AgO}_{\mathrm{X}}\right)$ were also prepared and applied in the oxidation reaction for comparison. Important reaction parameters such as temperature, time and solvent effect were optimized with the $\mathrm{Ru} / \mathrm{Al}_{2} \mathrm{O}_{3}$ catalyst in order to limit the formation of by-products such as veratrol (Scheme 1). The recyclability of the catalyst was further examined by performing consecutive reaction runs in order to demonstrate the viability of the system. 


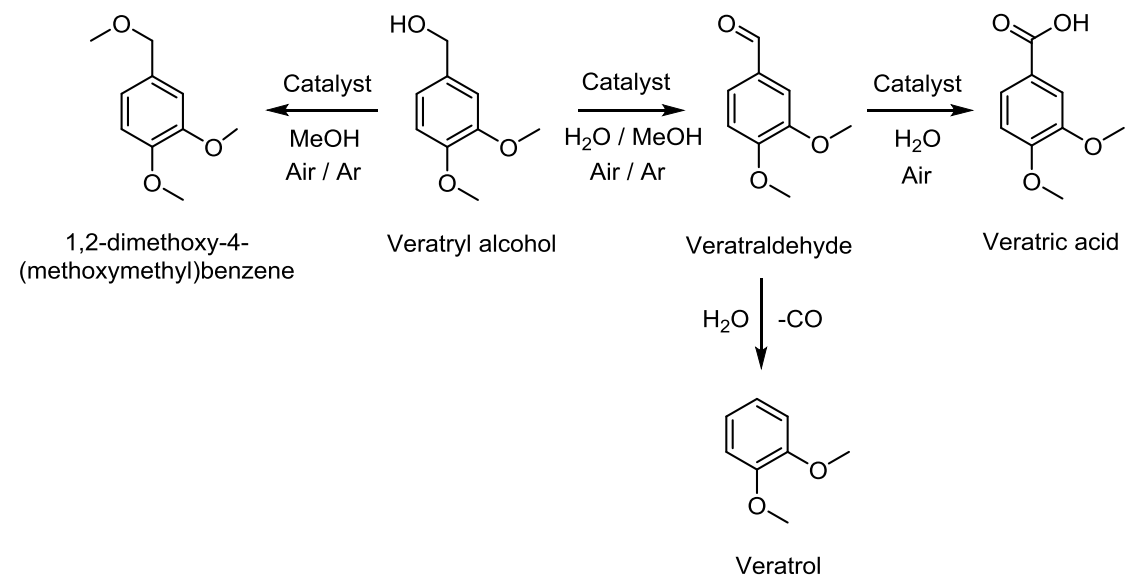

Scheme 1 Catalytic oxidation of veratryl alcohol (VA) to veratraldehyde (VAld) and other products.

\section{Experimental}

\subsection{Materials}

Veratryl alcohol (> 96\%, VA), veratraldehyde (99\%, VAld), veratrol (99\%) manganese(II)acetate tetrahydrate (> 99\%), cobalt(II)nitrate hexahydrate (p.a.), copper(II)acetate monohydrate (p.a.), silver(I)nitrate (p.a.), ruthenium(IV)oxide hydrate (> 99.9\%), ruthenium(III)acetylacetonate (> 97\%) and silica gel 60 were purchased from Sigma Aldrich. $\gamma$-Aluminium oxide (> 99\%) was provided by Saint Gobain as a generous gift. Compressed air ( 21\% oxygen) and argon (> 99.99\%) was purchased from Air Liquide, Denmark. All chemicals and gasses were used as received.

\subsection{Catalyst preparation}

The supported catalysts were prepared by wet impregnation. Appropriate amounts of ruthenium or other metal (manganese, cobalt, copper and silver) precursors were dissolved in water and either alumina or silica was slowly added to the aqueous solution of metal precursor and stirred for $3 \mathrm{~h}$. The slurry was then dried at $80{ }^{\circ} \mathrm{C}$ overnight in order to remove the water. Finally, the dried catalysts were calcined at $450{ }^{\circ} \mathrm{C}$ for $6 \mathrm{~h}$ in static air to get metal oxide (5 wt.\% with respect to 
metal) supported catalysts. The catalysts were stored in a desiccator and not pre-activated before use.

\subsection{Catalyst characterization}

TEM images of the Ru supported catalysts were recorded on a FEI Tecnai Transmission Electron Microscope at $200 \mathrm{kV}$ with samples deposited on a carbon support. EDS analysis was performed with an Oxford INCA system. Surface areas of the supported catalysts were determined by nitrogen sorption measurements at liquid nitrogen temperature on a Micromeritics ASAP 2020. The samples were outgassed in vacuum at $150{ }^{\circ} \mathrm{C}$ for $4 \mathrm{~h}$ prior to the measurements. The total surface areas were calculated according to the BET method.

\subsection{Catalytic oxidation reactions}

Catalytic experiments were performed in an autoclave (Microclave $50 \mathrm{ml}$ reactor, Autoclave Engineers) charged with an appropriate amount of VA, catalyst (100 mg) and water or methanol (10 $\mathrm{ml}$ ) as solvent. The reactor was pressurized with air (5 bars) or argon (20 bars) and heated to the desired reaction temperature. Mechanical stirring of the reactor $(300 \mathrm{rpm})$ was started when a temperature $20{ }^{\circ} \mathrm{C}$ below the set-point was reached. After the reaction, the autoclave was quenched in cold water where after filtered aliquots of the reaction mixture was subjected to GC-FID analysis (Agilent $6890 \mathrm{~N}$ instrument, HP-5 capillary column $30.0 \mathrm{~m} \times 320 \mu \mathrm{m} \times 0.25 \mu \mathrm{m}$ ) to quantify the conversion and product yield. The conversions of VA and yields of VAld were calculated based on series of individual standard solutions. The products were identified by GC-MS.

\section{Results and Discussion}

Initially, blank experiments without catalyst and with silica and alumina supports alone were carried out for the oxidation of VA to VAld in water. As expected, very poor yields of VAld $(<3 \%)$ were 
obtained confirming that the oxidation reaction did practically not occur in absence of a catalytically active metal (Table 1).

Table 1 Oxidation of VA to VAld over various supported catalysts in water ${ }^{\mathrm{a}}$

\begin{tabular}{|c|c|c|c|c|c|}
\hline \multirow{2}{*}{ Catalyst } & \multirow{2}{*}{$\begin{array}{l}\text { BET surface } \\
\text { area }\left(\mathrm{m}^{2} / \mathrm{g}\right)\end{array}$} & \multirow{2}{*}{$\begin{array}{l}\text { Conversion } \\
\text { of VA }(\%)\end{array}$} & \multicolumn{2}{|c|}{ Product yield (\%) } & \multirow[b]{2}{*}{ TON } \\
\hline & & & VAld & Veratrol & \\
\hline $\mathrm{Ru} / \mathrm{Al}_{2} \mathrm{O}_{3}(1)^{\mathrm{b}}$ & 166 & 93 & 67 & 3 & 8 \\
\hline $\mathrm{Ru} / \mathrm{Al}_{2} \mathrm{O}_{3}(2)^{\mathrm{c}}$ & 152 & 77 & 37 & $<1$ & 4 \\
\hline $\mathrm{Ru} / \mathrm{SiO}_{2}{ }^{\mathrm{b}}$ & 422 & 96 & 46 & $<1$ & 6 \\
\hline $\mathrm{Mn} / \mathrm{Al}_{2} \mathrm{O}_{3}$ & 152 & 69 & 17 & $<1$ & 1 \\
\hline $\mathrm{Al}_{2} \mathrm{O}_{3}$ & 204 & 46 & 3 & 0 & - \\
\hline $\mathrm{SiO}_{2}$ & 472 & 59 & 3 & 0 & - \\
\hline- & - & 34 & 2 & 0 & - \\
\hline
\end{tabular}

\footnotetext{
${ }^{\mathrm{a}}$ Reaction conditions: $100 \mathrm{mg} \mathrm{VA}, 100 \mathrm{mg}$ catalyst (5 wt. $\%$ metal), $10 \mathrm{ml}$ water, $160{ }^{\circ} \mathrm{C}, 5 \mathrm{~h}, 5 \mathrm{bar}$ air. ${ }^{\mathbf{b}}$ Catalyst prepared using ruthenium(IV) oxide hydrate precursor. ${ }^{\mathbf{c}}$ Catalyst prepared using ruthenium(III) acetylacetonate precursor. $\mathrm{TON}=\mathrm{mmol}$ formed $\mathrm{VAld} / \mathrm{mmol}$ metal in catalyst.
}

The yield of VAld increased significantly from 3 to $37 \%$ when the $\mathrm{Ru} / \mathrm{Al}_{2} \mathrm{O}_{3}$ (2) catalyst made with ruthenium(III) acetylacetonate was applied in the reaction. Encouragingly, the VAld yield was improved even further to $67 \%\left(62 \%\right.$ selectivity) for the $\mathrm{Ru} / \mathrm{Al}_{2} \mathrm{O}_{3}$ (1) catalyst made with ruthenium(IV) oxide hydrate. In comparison, the activity as well as the selectivity (25\%) of the $\mathrm{Mn} / \mathrm{Al}_{2} \mathrm{O}_{3}$ catalyst was much lower than $\mathrm{Ru} / \mathrm{Al}_{2} \mathrm{O}_{3}$ (1) and a corresponding yield of $17 \%$ VAld was only observed. TONs were calculated for the reactions based on the formation of VAld with respect to the total amount of metal present in the catalyst and are also given in Table 1. The TON for 
$\mathrm{Ru} / \mathrm{Al}_{2} \mathrm{O}_{3}$ (1) was found to be 8 , which was much higher than $\mathrm{Ru} / \mathrm{Al}_{2} \mathrm{O}_{3}(2)(\mathrm{TON}=4)$ as well as $\mathrm{Mn} / \mathrm{Al}_{2} \mathrm{O}_{3}$ for the formation of VAld.

In order to understand the discrepancy in activity of the $\mathrm{Ru} / \mathrm{Al}_{2} \mathrm{O}_{3}$ catalysts synthesised with the two different precursors, the catalysts were subjected to surface area measurement and microscopic studies. As shown in Table 1, no significant difference in the surface area of $\mathrm{Ru} / \mathrm{Al}_{2} \mathrm{O}_{3}(1)$ and $\mathrm{Ru} / \mathrm{Al}_{2} \mathrm{O}_{3}$ (2) was found. However, a considerable change in particle sizes on the $\mathrm{Ru} / \mathrm{Al}_{2} \mathrm{O}_{3}$ catalysts was observed from TEM images (Fig. 2). Here, it can be inferred that $\mathrm{Ru} / \mathrm{Al}_{2} \mathrm{O}_{3}$ (1) contained $\mathrm{RuO}_{\mathrm{X}}$ particles with a size range between $20-30 \mathrm{~nm}$, whereas $\mathrm{Ru} / \mathrm{Al}_{2} \mathrm{O}_{3}(2)$ had particles with 5-10 fold larger size ranging from $100-200 \mathrm{~nm}$. This suggests that $\mathrm{RuO}_{\mathrm{X}}$ particle sizes played a significant role on the conversion of VA to VAld, thus signifying the importance of choosing the suitable metal precursor when making active $\mathrm{Ru} / \mathrm{Al}_{2} \mathrm{O}_{3}$ catalysts. When changing the support from $\mathrm{Al}_{2} \mathrm{O}_{3}$ to $\mathrm{SiO}_{2}$ the comparable VAld yield (46\%) of catalysts made with the ruthenium(IV) oxide hydrate precursor decreased by $20 \%$ after $5 \mathrm{~h}$ of reaction, thus revealing a possible support role. However, the $\mathrm{Ru} / \mathrm{SiO}_{2}$ catalyst had a much higher surface area than $\mathrm{Ru} / \mathrm{Al}_{2} \mathrm{O}_{3}$ (1) making a direct comparison difficult.

In all the reactions with the VA and the Ru catalysts the by-product veratrol (see Scheme 1) was only found in low yields $<3 \%$ (also at $\leq 140{ }^{\circ} \mathrm{C}$, results not shown), even though previous reports have shown that Ru-based catalysts are efficient for decarbonylation of aromatic and aliphatic aldehydes as applied here [37-38]. The $\mathrm{pH}$ of the reaction mixture was measured before and after the reaction. Here a change from $\mathrm{pH}$ of 7-8 before reaction to 5-6 after reaction was found, suggesting us to speculate that veratric acid (not detectable by our GC, GC-MS and HPLC equipment) was formed by over oxidation, as also observed in previous studies [12]. Veratric acid thus also accounts for some of the missing material in the carbon balance. 

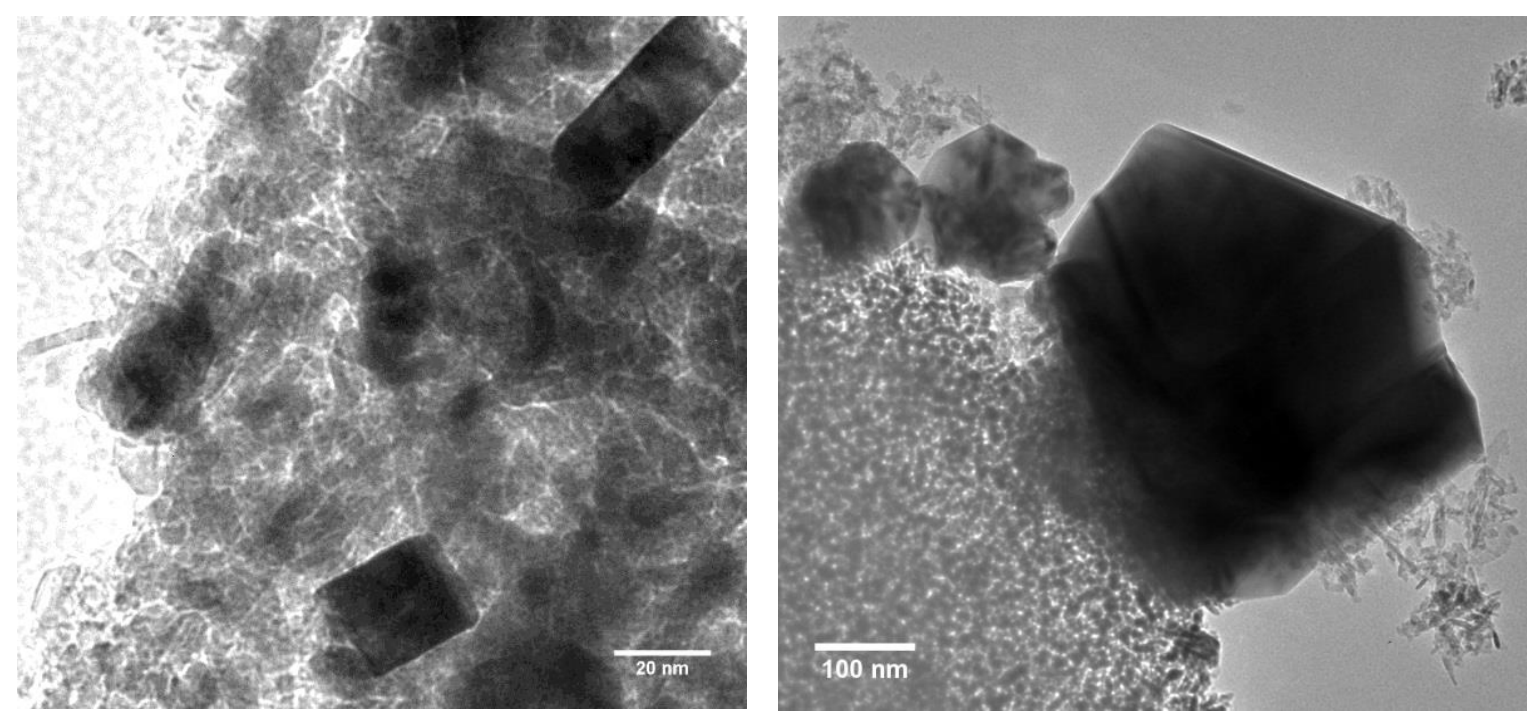

Fig. 2 High-resolution TEM images of (left) 5 wt.\% Ru/ $\mathrm{Al}_{2} \mathrm{O}_{3}$ (1) and (right) 5 wt.\% $\mathrm{Ru} / \mathrm{Al}_{2} \mathrm{O}_{3}(2)$.

In order to examine in more detail how VAld and veratrol formation developed during the reaction in water the reaction time was prolonged to $20 \mathrm{~h}$ in Ar, and the results are summarised in Table 2 and in the accompanying time-course study on Fig. 3. The results showed that $\mathrm{Ru} / \mathrm{Al}_{2} \mathrm{O}_{3}(1)$ yielded $69 \%$ of VAld along with $27 \%$ of veratrol and full conversion after $20 \mathrm{~h}$ or reaction, with the former being essentially the same as the yield obtained after $5 \mathrm{~h}$ of reaction. Likewise, $\mathrm{Ru} / \mathrm{SiO}_{2}$ yielded $69 \%$ of VAld and less than $1 \%$ of veratrol along with quantitative VA conversion. Catalysts with alternative metals $(\mathrm{Co}, \mathrm{Cu}, \mathrm{Ag}$ and $\mathrm{Mn})$ supported on $\mathrm{Al}_{2} \mathrm{O}_{3}$ gave VAld yields between 5 and $26 \%$ and low amounts of veratrol $(\leq 6 \%)$. TONs for all the metal supported catalysts were calculated and are also reported in Table 2. Apparently, it can here be seen that the TONs for $\mathrm{Ru} / \mathrm{Al}_{2} \mathrm{O}_{3}(1)$ and $\mathrm{Ru} / \mathrm{SiO}_{2}$ were similar and significantly higher than the TONs for the catalysts based on the alternative metals. Notably, the time-course study further revealed that an excellent VAld yield of $89 \%$ could be reached after about $8 \mathrm{~h}$ of reaction, where the veratrol yield was less than $2 \%$. When the reaction time exceeded $8 \mathrm{~h}$, the veratrol yield increased at the expense of the VAld yield corroborating that decarbonylation of VAld to veratrol occurred. In a separate experiment using 
VAld as substrate, a very low yield of veratrol $(<2 \%)$ was obtained after $5 \mathrm{~h}$ in line with the results from the time course-study.

Table 2 Oxidation of VA in water and methanol over various metal supported catalysts ${ }^{\mathrm{a}}$

\begin{tabular}{lccccc}
\hline \multirow{2}{*}{ Catalyst } & VA Conversion & \multicolumn{3}{c}{ Product Yield (\%) $^{\mathrm{b}}$} & \\
\cline { 3 - 5 } & $(\%)$ & VAld & Veratrol & VA-Ether $^{\mathbf{d}}$ & TON \\
\hline $\mathrm{Ru} / \mathrm{Al}_{2} \mathrm{O}_{3}(1)^{\mathrm{c}}$ & $>99(90)$ & $69(22)$ & $27(17)$ & $(36)$ & $9(3)$ \\
$\mathrm{Ru} / \mathrm{SiO}_{2}{ }^{\mathrm{c}}$ & $99(96)$ & $69(10)$ & $<1(<1)$ & $(67)$ & $8(1)$ \\
$\mathrm{Co} / \mathrm{Al}_{2} \mathrm{O}_{3}$ & $61(56)$ & $13(7)$ & $4(6)$ & $(16)$ & $2(1)$ \\
$\mathrm{Cu} / \mathrm{Al}_{2} \mathrm{O}_{3}$ & $>99(56)$ & $5(13)$ & $1(8)$ & $(37)$ & $<1(2)$ \\
$\mathrm{Ag} / \mathrm{Al}_{2} \mathrm{O}_{3}$ & $34(89)$ & $26(2)$ & $<1(22)$ & $(34)$ & $3(<1)$ \\
$\mathrm{Mn} / \mathrm{Al}_{2} \mathrm{O}_{3}$ & $81(47)$ & $23(24)$ & $6(<1)$ & $(22)$ & $3(3)$ \\
\hline
\end{tabular}

${ }^{\mathrm{a}}$ Reaction conditions: $170 \mathrm{mg}$ VA, $170 \mathrm{mg}$ catalyst (5 wt.\% metal), $10 \mathrm{ml}$ water, $160{ }^{\circ} \mathrm{C}, 20 \mathrm{bar}$ argon, $20 \mathrm{~h} .{ }^{\mathrm{b}}$ Numbers in parenthesis are results from experiments performed in methanol $(10 \mathrm{ml}) .{ }^{\mathrm{c}}$ Catalyst prepared using ruthenium(IV) oxide hydrate precursor. ${ }^{\mathrm{d}}$ VA-ether refers to 1,2 -dimethoxy4-(methoxymethyl)benzene. TON $=$ mmol of VAld formed $/ \mathrm{mmol}$ of metal in catalyst.

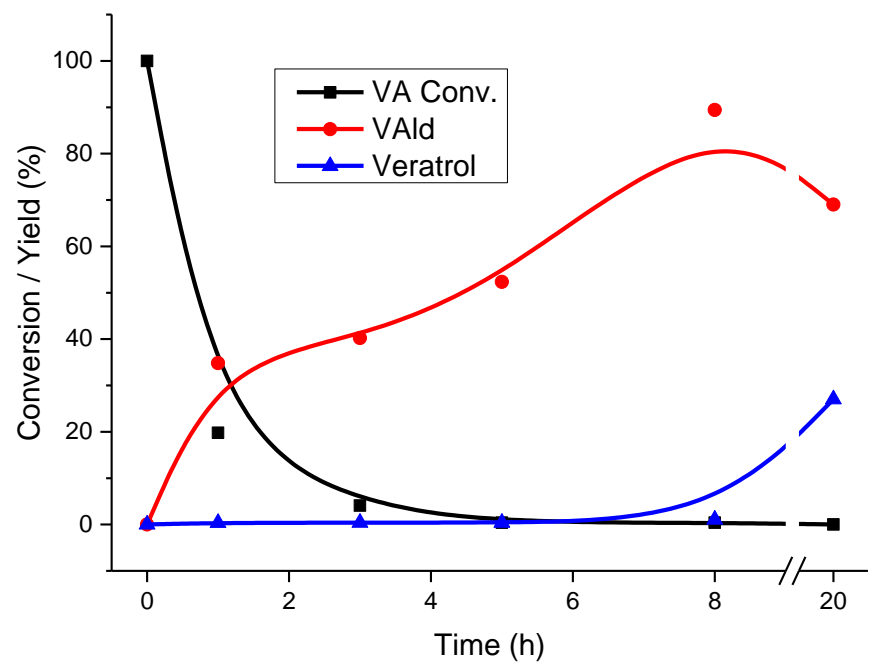


Fig. 3 Time-course study for VA conversion into VAld with $\mathrm{Ru} / \mathrm{Al}_{2} \mathrm{O}_{3}$ (1) in water. Reaction conditions: $100 \mathrm{mg}$ VA, $100 \mathrm{mg}$ catalyst (5 wt.\% metal), $10 \mathrm{ml}$ water, $160{ }^{\circ} \mathrm{C}, 5$ bar air. Each set of data on the time axis is from individual experiments.

When the solvent was changed from water to methanol, the yield of VAld obtained with $\mathrm{Ru} / \mathrm{Al}_{2} \mathrm{O}_{3}$ (1) (at $160{ }^{\circ} \mathrm{C}$ and 20 bar Ar) drastically reduced from 69 to $22 \%$. Instead the formation of the methyl ether by-product of VA, 1,2-dimethoxy-4-(methoxymethyl)benzene (VA-ether) prevailed (see Scheme 1). The highest yield of VA-ether (67\%) was obtained over $\mathrm{Ru} / \mathrm{SiO}_{2}$. Concomitantly, the yield of VAld was reduced to $10 \%$ with the latter catalyst, which was about five times lower than the corresponding yield attained in water with 5 bar of air after $20 \mathrm{~h}$ reaction (Table 2). This substantiate that the presence of oxygen favoured the conversion of VA to VAld by oxidation rather than dehydrogenation which, on the other hand, prevailed under argon atmosphere. Moreover, when the experiment was carried out in methanol at 5 bar air pressure, no improvement in VAld yield (15\%) was observed (results not shown), inferring that water was the preferred solvent for the oxidation of VA to VAld in the presence of air.

Catalyst recyclability is important for the viability of a catalyst system. Accordingly, the $\mathrm{Ru} / \mathrm{Al}_{2} \mathrm{O}_{3}$ (1) catalyst was subjected to reuse studies in the VA oxidation reaction. After each reaction run the catalyst was recovered by filtration, thoroughly washed with water, dried overnight at $80{ }^{\circ} \mathrm{C}$ and finally calcined at $450{ }^{\circ} \mathrm{C}$ for $6 \mathrm{~h}$ before being used in the next reaction. As depicted in Fig. 4, the conversion of VA and the yield to VAld decreased noticeably after three reaction cycles from 93 to $65 \%$ and 67 to $34 \%$, respectively, while the VAld selectivity remained above $50 \%$. Part of the loss of catalytic activity could be due to loss of catalyst during the separation or due to increase in particles size of ruthenium during the additional calcinations, as previously observed in supported $\mathrm{Ru}$ catalysts [39]. The used $\mathrm{Ru} / \mathrm{Al}_{2} \mathrm{O}_{3}$ (1) catalyst was after the consecutive reactions subjected to 
surface area measurement. Here the BET surface area was found to be increased almost $20 \%$ from the original 166 to $201 \mathrm{~m}^{2} / \mathrm{g}$, which resembled the alumina support alone $\left(204 \mathrm{~m}^{2} / \mathrm{g}\right)$. Combined, the activity drop as well as the increased surface area could indicate possible Ru leaching from the support to the reaction solutions. However, leaching of Ru from this type of catalyst materials under similar conditions has previously shown to be a minor issue [39-40].

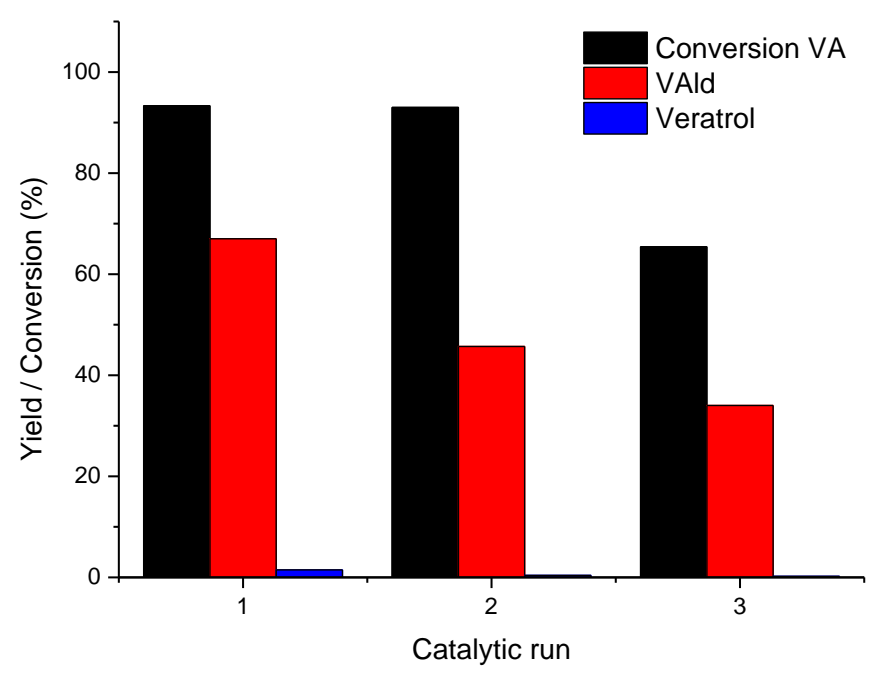

Fig. 4 Reuse of $\mathrm{Ru} / \mathrm{Al}_{2} \mathrm{O}_{3}$ (1) catalyst for three consecutive VA oxidation reactions in water. Reaction conditions: VA to catalyst mass ratio $=1.04,10 \mathrm{ml}$ water, $160{ }^{\circ} \mathrm{C}, 5 \mathrm{~h}, 5$ bar air.

\section{Conclusions}

$\mathrm{Ru} / \mathrm{Al}_{2} \mathrm{O}_{3}$ (1) (prepared with ruthenium(IV)oxide hydrate precursor) demonstrated to give the highest yield to VAld (89\%) at full conversion of VA in water at $160{ }^{\circ} \mathrm{C}$ and 5 bar air after $8 \mathrm{~h}$ of reaction. An analogous catalyst prepared with ruthenium(III) acetylacetonate precursor gave a 30\% lower VAld yield, which by TEM analysis was correlated with the presence of larger $\mathrm{RuO}_{\mathrm{X}}$ particles in the latter catalyst. A significant amount of veratrol by-product was formed by decarbonylation of VA with $\mathrm{Ru} / \mathrm{Al}_{2} \mathrm{O}_{3}$ after prolonged reaction time, suggesting that control of the 
reaction time was necessary to obtain VAld in high yield. Moreover, by conducting the reaction in methanol instead of water with 20 bars of $\mathrm{Ar}$ resulted in a lower yield of VAld (by dehydrogenation), while VA-ether formation was facilitated (36\% yield). TONs for the conversion of VA to VAld was found to be 8 with $\mathrm{Ru} / \mathrm{Al}_{2} \mathrm{O}_{3}$ (1) in air, which was about $50 \%$ higher than the TONs obtained with $\mathrm{Ru} / \mathrm{Al}_{2} \mathrm{O}_{3}(2)$ and $\mathrm{Ru} / \mathrm{SiO}_{2}$. The TON increased slightly with $\mathrm{Ru} / \mathrm{Al}_{2} \mathrm{O}_{3}(1)$ at longer reaction time when the reaction was carried out under Ar due to dehydrogenation of VA to VAld. It was possible to recycle the $\mathrm{Ru} / \mathrm{Al}_{2} \mathrm{O}_{3}(1)$ catalyst and apply it in three consecutive reaction runs. However, the VA yield decreased significantly between each run, probably due to insufficient catalyst stability under the reaction conditions. The unsatisfying recyclability is a major drawback, which obviously hamper implementation of the $\mathrm{Ru} / \mathrm{Al}_{2} \mathrm{O}_{3}$ catalyst for lignin valorisation. Continuation of the work is currently in progress in search for a suitable water-tolerant and stable supported catalyst.

\section{Acknowledgements}

The authors appreciate financial support to the work from The Danish Agency for Science, Technology and Innovation (International Network Programme, 12-132649), Haldor Topsøe A/S and the Technical University of Denmark.

\section{References}

[1] The oil drum, discuss about energy and our future (2013) Luis de Soussa, Luxemburg. http://www.theoildrum.com/node/10009.

[2] Corma A, Iborra S, Velty A (2007) Chem. Rev. 107: 2411-2502.

[3] Saravanamurugan S, Holm MS, Taarning E (2010) Science 328: 602-605. 
[4] Holm MS, Pagan-Torres, YJ, Saravanamurugan S, Riisager A, Dumesic JA, Taarning E (2012) Green Chem. 14: 702-706.

[5] Saravanamurugan S, Riisager A (2013) ChemCatChem 5: 1754-1757.

[6] Patil PT, Armbruster U, Richter M, Martin A (2006) Energy \& Fuels 311: 4713-4722.

[7] Zakzeski J, Bruijnincx PCA, Jongerius AL, Weckhuysen BM (2010) Chem. Rev. 110: 35523599.

[8] Amen-Chen C, Pakdel H, Roy C (2001) Bioresour. Technol.79: 277-299.

[9] Zhao C, Lercher JA (2012) ChemCatChem 4: 64-68.

[10] Q. Xiang, Y. Y. Lee, Appl. Biotechnol. 2000 153: 84-86

[11] Díaz-González M, Vidal T, Tzanov T (2011) Appl. Microbiol. Biotechnol. 89: 1693-1700

[12] Crestini C, Crucianelli M, Orlandi M, Saladino R (2010) Catal. Today 156: 8-22.

[13] Jha A, Chandole T, Pandya R, Roh HS, Rode CV (2014) RSC Adv. 4: 19450-19455.

[14] Lange H, Decina S, Crestini C (2013) Eur. Polymer. J. 49: 1151-1173.

[15] Shannon S. Stahl, Alireza Rahimi (2014) US Patent 2014/0235838

[16] Kirk TK, Farrell RL (1987) Ann. Rev. Microbiol 41: 465-505.

[17] Larson TM, Anderson M, Rich JO (2013) Biotechnol. Lett. 35: 225-231.

[18] Cui F, Dolphin D (1995) Biorg. Med. Chem. 3: 471-477.

[19] Labat G, Meunier B (1989) J. Org. Chem. 54: 5008-5011.

[20] Zhu W, Ford WT (1993) J. Mol. Catal. 78: 367-378. 
[21] Zucca P, Sollai F, Garau A, Rescigno A, Sanjust E (2009) J. Mol. Catal. A: Chem. 306: 89-96.

[22] Kumar A, Jain N, Chauhan SMS (2007) Synlett 34: 411-414.

[23] Zucca P, Mocci G, Rescingo A, Sanjust E (2007) J. Mol. Catal. A: Chem. 278: 220-227.

[24] Sena-Martins G, Almeida-Vara E, Duarte JC (2008) Ind. Crops Prod. 27: 189-195.

[25] Sippola V, Krause O, Vuorinen T (2004) J. Wood Chem. Technol. 24: 323-340.

[26] Kervinen K, Korpi H, Mesu JG, Soulimani F, Repo T, Rieger B, Leskelä M (2005) Eur. J. Inorg. Chem.13: 2591-2599.

[27] Lahtinen P, Korpi H, Haavisto E, Leskelä M, Repo T (2004) J. Comb. Chem. 6: 967-973.

[28] Rochefort D, Boubonnais R, Leech D, Paice MG (2002) Chem. Commun. 1182-1183.

[29] Kervinen K, Korpi H, Leskelä M, Repo T (2003) J. Mol. Catal. A: Chem. 203: 9-19.

[30] Ambrose K, Bitu BB, Singer RD (2013) Can. J. Chem. 91: 1258-1261.

[31] Fan H, Yang Y, Song J, Ding G, Wu C, Yang G, Han B (2014) Green Chem. 16: 600-604.

[32] Yamaguchi K, Mizuno N (2002) Angew. Chem. Int. Ed. 41: 4538-4542.

[33] Zhan BZ, White MA (2003) J. Am. Chem. Soc. 125: 2195-2199.

[34] Gorbanev YY, Kegnæs S, Riisager A (2011) Top. Catal. 54: 1318-1324.

[35] Nie J, Xie J, Liu H (2013) J. Catal. 301: 83-91.

[36] Ruppert A, Weinberg K, Palkovits R (2012) Angew. Chem. Int. Ed. 51: 2564-2601.

[37] Domazetis G, Tarpey B, Dolphin D, James BR (1980) J. Chem. Soc., Chem. Commun. 20: 939-940. 
[38] Allen CL, Willams JMJ (2010) Angew. Chem. Int. Ed. 49: 1724-1725.

[39] Gorbanev YY, Kegnæs S, Hanning CW, Hansen TW, Riisager A (2012) ACS Catal. 2: 604612.

[40] Gorbanev YY, Kegnæs S, Riisager A (2011) Catal. Lett. 141: 1752-1760. 